\title{
Spørgsmål fra Danmark til de tysksprogede universiteter
}

\author{
Et ufuldendt udkast \\ af Grundtvig
}

Dette ufuldendte, men bemærkelsesværdige manuskript i Grundtvig-arkiver må ses som udtryk for de følelser, hvormed Grundtvig i årene 1816-19 betragtede begivenhederne $\mathrm{i}$ Tyskland efter Wienerkongressen 1815-16. Efter den 23. marts 1819 blev situationen dér en helt anden end den, som Grundtvig i dette udkast forudsæatter; man må derfor antage, at den foreliggende tekst er skrevet forud for denne ændring af situationen.

I perioden 1815-19 var der i Tyskland en stærk forventning om, at fyrsterne, hvis magt var genoprettet på Wienerkongressen, ville opfylde de løfter, de under krigen havde givet deres folk om en fri forfatning. Det skete imidlertid ikke eller kun i meget ringe udstrækning. Det er i denne situation, Grundtvig har skrevet det her offentliggjorte udkast, som indeholder en opfordring til professorerne ved de tyske universiteter, der går ud på, at de skal tilbyde fyrsterne deres medvirken som et mellemled mellem dem og folkene. Udkastet blev aldrig afsluttet, rimeligvis fordi situationen ændredes, da en student på åben gade havde dræbt forfatteren August von Kotzebue den 23. marts 1819. Der indførtes censur, de nydannede studenterforeninger opløstes, og universiteterne sattes under politiopsyn.

Manuskriptet, som findes i Grundtvig-arkivets fascikel 168, er - som de fleste af Grundtvigs få manuskripter på tysk - forsynet med mange rettelser mest af sproglig art, som her er taget til følge uden særlige bemærkninger. Fasc. 168 indeholder også et kort, ufuldendt udkast med overskriften "Gewissens-Fragen ", dvs. "Samvittighedsspørgsmål". Grundtvigs tysk er ikke let at oversætte. Det følgende må derfor kun betragtes som et forsøg.

Politiske spørgsmål

Når jeg begynder bagfra, er det ikke fordi jeg skulle anse mig for at være forpligtet dertil over for dem, der - idet de stiller alting på hovedet - sætter det legemlige over det åndelige, det timelige over det evige, men kun fordi det forekommer mig, at politikken i de seneste år er blevet eders egentlige sfære, den I med forkærlighed og hovedsageligt lever og ånder i, og fordi Europas politiske situation uimodsigeligt befinder sig i en krise, som også truer den menneskelige udvikling med en sig nærmende fare, ja synes fuldstændig at skuffe det håb, dog endelig engang at se et tempel for den sande visdom: for den levende Sandhed på jorden. Endnu står de tømmerværker, som Ånden gennem århundreder møj- 
sommeligt har oprejst og befæstet, endnu ligger for vore øjne de udkast, som kunstnere og fuskere har tegnet til bygningen, ruinerne af dristige og enfoldige, store og små, stedse mislykkede forsøg på, før det var tiden dertil, at bygge. Endnu står og ligger foran os, hovedsageligt hos eder, de næsten uoverskuelige materialer dertil, de advarende og lærerige eksempler af alle slags, det mere og mere dyrtkøbte udbytte af den samlede menneske-erfaring. Endnu har vi det - men aldrig siden omstyrtningen af det gamle romerske rige mindede tidernes tegn i den grad som nu alle vågende ånder om det store Sandhedens Ord: al menneskenes herlighed er som græssets blomster, græsset er hentørret, dets blomster affaldet.

Dér står de bævende, de dybt rystede stater i den nyere, den europæiske folkeverden, disse vugger for den opadstræbende Ånd, for alle slags forsken og lærdom. Hvad vil der snart, som det synes, blive af dem? Og styrter de sammen, hvad ligger der da ikke begravet under dem, jordet, uden evne til nogen opstandelse?

Vi kender de barbarer, som har lejret sig på grænsen af den dannede verden og kun venter på det øjeblik, da den indre forvirring og splittelse tillader dem at skænde og brænde af hjertens lyst. Det er, det véd vi, ikke germanske og nordiske heltes bjergkæder med dybe skakter, som sprængt af Ånden og opladt ved Livets Ord afslørede usete skatte og førte deres dværgbeboere, sindrige, lysglade drenge, frem for dagen og ved Guds hjælp århundreder igennem har smedet derpå og formet deraf, hvad der får os til at undres, når vi ser derpå. Nej, der findes ikke mere sådanne på Jorden, det er kun vulkanske isbjerge, der nu truer med at vælte sig hen over den svækkede, udartede folkeverden for at tilintetgøre alt, hvad der har levende ånde og med alle tiders åndelige bygninger, med den store - ikke alexandrinske, men herkuliske - hob af bøger at opvarme deres bade eller, for at gøre kort proces, rejse et mægtigt bål, hvis ildsøjle ville kunne forkynde for Himmelen, at dens elskede barn, menneskeånden, i tidernes verdens-hav var strandet og med alle sine skatte blevet et rov for de rasende bølger. Vistnok har jeg hørt det, og tør bygge derpå, at der vandrer en slægt under solen, som ikke behøver at frygte for sig selv, når hedninger må fortvivle og kongeriger falde, efterkommerne af dem, der med Korahs børn synger: vi næ- 
rer ingen frygt, omend havet vælter sig og raser og bjergene styrter på grund af dets voldsomhed; dog skal Gudsstaden holde sig munter med sine vandbække, da de er den Højestes hellige boliger; Gud er derinde hos dem, derfor vil de forblive i god behold, Gud hjælper dem snart. Men, omend Gud - hvad han formår opvækker Abraham børn af stene, ja, omend det håb, som flygter til Amerika, skulle være lige så vel grundet, som det forekommer mig forfængeligt, hvad da: alle os, der er født og opdraget til det åndelige, har folkene gennem deres ånd sat til vægtere, og ser vi sværdet komme og blæser ikke i basunerne for at advare folket, så bliver dog vel de, hvem sværdet ikke rammer for deres synders skyld, borttaget, men deres blod vil Herren dog kræve af vore hænder, ja, vore hjerters blod vil de børn, hvis uadvarede forældre fjenden dræbte, og som ikke selv må trælle som slaver for verdens-elementerne, med fortvivlelsens latter uddrikke for dermed for et øjeblik at køle deres brændende indvolde.

Havde vi da - vi, der kalder os folkenes øjne - havde vi end intet tilfælles med deres hjerter, så måtte vi jo dog - vi er dog ikke blot blinde vinduesruder, men opladte øjne - vi måtte jo dog for vor egen skyld og af den kærlighed til vort åndelige arbejde som, trods den vandflod, der skyller over os, uudslukkelig brænder $\mathrm{i}$ os, vi måtte dog se til, at fjenden i det mindste ikke overrasker os, at udslettelsen af mindesmærkerne og ødelæggelsen af værkstederne for Ånden iblandt os, omend den ikke kan forhindres, dog i det mindste bliver forsinket så meget, at det springer os alle $\mathrm{i} ø j-$ nene, at Ånden har bosat sig andensteds, hvor den fra en ny arne kalder til et nyt fædreland på Jorden. Dersom det da vil være kommet så vidt, at vore advarende stemmer dør hen som i ørkenen, dersom hænderne og fødderne anmasser sig retten til at smække med tungen og trampe i gulvet for at sige os, at øjnene, fordi de ikke er hænder og fødder, ikke hører kroppen til, da tilråber vi hinanden så højt vi kan, uden at hænder og fødder forstår det: rejs eder og lad os gå herfra, lad os ryste støvet af vore fødder og fare på vingede heste derhen, hvor Ånden har oprejst sit banner, og hvor hjerterne kalder os hen.

Således skulle jeg mene sømmer det sig for os at tænke, at tale og at handle, og det spørgsmål stiller sig nu af sig selv, hvorledes jeg skal stille spørgsmålet til eder: har vi advaret folkene, har vi, i den grad det er vor opgave, arbejdet på at hjælpe på de løse bånd, 
hvor de endnu ikke er bristet, for i det mindste endnu et stykke tid at sammenknytte, hvad der ikke kan opløses uden at fremkalde døden eller rettere uden ved forrådnelse at tilkendegive den allerede indtrådte død.

Med retmæssig grund retter jeg spørgsmålet særlig til eder, I tysksprogede universiteter, thi eder udvalgte Ånden øjensynligt i de senest henrundne tider til vogtere af den hellige borg, stillede eder som Heimdal på Himmelbjerget på grænsen af gudeverdenen, for som den pålidelige vagtpost at advare os mod thyrsussvingerne og for at I, når I allerede på lang afstand på støvskyerne og hovslagene forstod, at Muspel-sønnerne besteg deres lynsnare og ildsprudende gangere for at nedbryde himmelbroen og forøde gudeverdenen, da med lynets hast og Giallarhornet for munden kunne vække alle guder og helte, på det at sejren, omend dyrt købt med et hav af helteblod, skulle blive gudernes, dvs. den guddommelige Ånds. I, som i gudeverdenen ligesom den gamle himmelvogter hører græsset gro og ulden vokse, og som han kun behøver fuglenes søvn, I, hvis stemme, når den lyder, giver genlyd fra alle bjerge i den oversanselige verden, og som bor i et folk, hvis hørelse, beslægtet med eders, fornemmer selv eders sagteste hvisken og, om det blot er muligt, straks gentager eders ord $\mathrm{i}$ handlinger - hvad har I gjort for at advare folkene, for i det mindste at beskytte eders nærbeslægtede og os Hyperboræere, der har agtet på eders ord som på guddommelige orakelsprog, for i det mindste at beskytte dem og os mod den strømhvirvel, der truer med at opsluge alle stater? - I beklager eder over, at I er blevet bagtalt og tilsværtet hos fyrsterne, og hvordan det nu end er gået til, sandelig, det er et overmåde stort onde, i høj grad ildevarslende, at der har udspundet sig en gensidig mistro imellem fyrsterne og eder, det kan ikke vare længe, før der kommer de beskeste frugter deraf, men hvad har I gjort for at oplyse det tusmørke, for at udjævne den usalige tvist?

Har I åbent og ligefrem klargjort for regeringerne, hvor umuligt det er i vore tider at byde over tanke-havet, at forsøget derpå ikke er langt klogere, men langt fordærveligere end at piske de oprørte bølger, at når man med vold berøver ordet dets fjedrede vinger, giver man det kun vinger af ild, der straks antænder alt, hvad de blot rører ved, og således i mørket stikker ild i et bål, som bliver ved med at brænde, indtil det når afgrunden? Har I 
særligt klargjort det for dem, at var den mistanke grundet, som de har kastet over eder, var flertallet imellem eder virkelig skyldig i onde anslag, da ville ingen kontrolforanstaltninger, censur eller straffe strække til for at værge sig imod ulykken, eftersom det ikke er de gøende hunde, der er de farligste, og rævene først åbner munden, når det er tid til at bruge tænderne?

Har I med eders liv garanteret regeringerne eders afsky mod alle voldsomme omvaltninger, det vil sige: har I med historien belært dem om, at når det sanselige driver folkets kraft til at gribe til våben mod det åndelige element, så mister I lige så vel som fyrsterne eders land og folk og dermed eders eget liv, idet det jo kun er et skyggespil at figurere på katederet såvel som på tronen, dersom folket ikke ønsker ledelse, men kun følgagtighed, ikke ønsker at føres videre, men kun at få sine ønsker fremført. Kort sagt: Har I ladet dem forstå, hvad I jo vel længe selv har forstået, at det er eder, der fremstiller (repræsenterer) det sig dannende folk, ligesom fyrsten den til uddannelse nødvendige folkekraft, således at enhver anden repræsentation ville være en uting, hvorigennem kraften ville blive adsplittet og opbrugt til sanselige formål, dannelsens linie afbrudt og folkelivets åndelige formål gjort til intet. Har I på dette grundlag forhandlet med regeringerne om at formidle en overenskomst, gennem hvilken ligevægten og det åndelige folkeliv det vil sige den videre uddannelse i det mindste foreløbig ville kunne sikres?

Fyrsterne har lovet deres enkelte folk en repræsentativ forfatning, og i det rige, hvor der altid i det mindste tilsyneladende har været en sådan, afhænger muligheden for at skabe ro af en mere end tilsyneladende opfyldelse af dette højtidelige løfte. Vistnok er nu de visestes ord den eneste fribårne folkerepræsentant og pressefrihed som grundlov for den sande frihed den bedste form for deltagelse i rådslagningen, som fyrsterne kan skænke deres folk. Men for at forstå dette måtte mængden være klogere og for at tro det hjerteligere end man tør formode, og denne frihed måtte vel af den grund blive anskueliggjort i universiteterne - på hvilken måde forstår I sikkert bedre end jeg, når blot I ikke af den grund skulle få det indfald at føre ordet alene, fordi I udtrykker det i embeds medfør. Sandt nok, jeg tror næppe, at tyske regeringer ville eller kunne foretrække at udmatte sig ved kamp mod tidens strøm, dersom I viser dem en så ærefuld løsning, gennem hvilken 
de uden at miste livet eller blive hensat på skyggetroner ville kunne opfylde deres løfter og berolige deres undersåtter, og dette så meget mindre, som pressefriheden jo i det skjulte fra gammel tid er blevet udøvet i Tyskland og også vil blive det $\mathrm{i}$ fremtiden, indtil en revolution afføder et altomfattende militært despoti - ganske som det har været gammel tysk sæd og skik at rådføre sig med universiteterne.

Har I foreslået noget sådant, f.eks. at supplere Forbundsdagen med delegerede fra alle universiteter, der repræsenterede hele folket på samme måde som ministrene hele regeringen; - foreslået og gjort udførligt rede derfor - foreslået at overlade pennen i alle studerede og embedsmænds hånd omtrent den samme frihed, som man almindeligvis under tungen, og ligesom man endnu ikke syr læberne sammen på injurianten, at man så heller ikke stopper munden på skribenten, omend et usømmeligt og strafbart ord er fløjet ud deraf.

Men måske behøver I ikke mere staten for at nå eders mål, måske har I ikke mer at gøre på videnskabens område? Er I allerede blevet færdige med eder selv og med bøgerne, så at der kun var brug for enkelte blade til at fuldstændiggøre menneskehedens store bog, måske kun en kort historisk beskrivelse af den grundige statsomvæltning, et værk, som I udfra de sædvanlige evner roligt tænker at kunne overlade avisskriverne, medens I selv som hovedhjul i den store dampmaskine, der forvandler alt til støv, afslutter eders ærefulde løbebane. Ja, i fuldt alvor må jeg spørge eder, om I virkelig tror, at alle dages aften er kommet, eller at i det mindste Historiens Dommedag er oprundet, på hvilken I kun har den opgave at dømme verden og Jordens stormænd efter (lov-) bøgerne.

I kunne vel skælde mig ud for en næsvis knægt, siden jeg lader så fjantede spørgsmål udgå til institutter, hvis blotte navn kunne belære mig om noget bedre, og som jo dog vel selv bedst skulle vide, hvad de hedder. Det være også langt fra mig at benægte, at det ville være tåbeligt at være skabt til et studium generale (alment studium) og dog kun et øjeblik bilde sig ind, at man kunne gælde derfor uden videnskabeligt at bære indholdet af hele menneskelivet i sig. Men er det min skyld eller eders, at talen her desuagtet er om så tåbelige tanker? For hvem er det ikke indlysende, at dersom store vidensområder endnu henligger næsten uopdyrkede, 
og dersom endnu selv det indhøstede ligger dels i laderne, dels på jorden, og i det højeste på møllen, udsat for utøj, uspiseligt for folket, så at det, når sagerne står således, er højst forhastet at smede plovjern om til lanser og forvandle ungdommen til gymnaster ("Turnern"). Eller tror I virkelig, at videnskabelige foretagender hos et folk, der trænger ind i rådsstuerne for ikke længere at blive holdt for nar, skulle kunne være så elskede, at man over dem skulle kunne glemme det, man kalder sin fordel, ja, endog at de udmærkede hoveder skulle foretrække forskningens vanskelige, smalle vej fremfor talens brede, jævne kørevej til ærens højder? Hvem ville dog kalde det sandsynligt, at de unge trods begæret efter ry og lysten til straks at se sine tanker virkeliggjort snarere skulle kunne beherske disse mægtige drifter end de mænd, der har mere end smagt de grundige kundskabers sødme, og som ikke kan være uvidende om, hvor lidt folkegunsten afgiver en fast grund til at bygge deres æres og deres lykkes slotte på, og hvor hurtigt ynglingens strålende forhåbninger om at skabe en ny verden med deres Bliv blegner og taber deres glans! Sandelig - når I ikke des mindre - I, som kun søvnigt driver jeres særlige beskæftigelse - indånder ungdommen eders længsel efter et livligt, folkeligt liv ude på torvet, så har man lov til, ja man må nødvendigvis spørge: er I allerede færdige, eller er I blevet trætte af at lære og forske, har I fundet de Vises sten eller ved moden overvejelse opdaget, at den ikke lader sig finde eller dog ikke er den møje værd, som eftersøgningen allerede har kostet og yderligere ville koste? Jeg tænker mig, at det ikke er en af delene, men noget af begge dele, som driver eder til at fordybe og fortabe eder i det praktiske. Sandsynligvis tror I at have ydet det højeste i videnskaberne, om ikke det højeste, som er tænkt, så dog det højeste, der inden for de menneskelige sjæleevners mål lader sig gøre, idet I hos de viseste fra alle tider omhyggeligt spurgte efter, hvad de havde begrebet, erfaret og udtænkt, og idet I efter de mangfoldigste, ofte dristigste forsøg på at trænge ned i menneskeåndens og menneskehjertets dybder endelig erkendte, at det var en forfængelig og forgæves stræben. I tror sandsynligvis, at de eneste fremskridt, der er ære værd, og som endnu mangler, for åbenbart angår folkenes timelige velvære og. fremskridt til, at man skulle befrygte, at de skulle blive hæmmet og ikke snarere fremmet ved verdensklogskab. Astronomien, fysikken, kemien, zoologien og 
botanikken og endelig matematikken er - således synes I at tænke - så inderligt sammenflettet med hverdagslivet; deres nytte og nødvendighed er forlængst blevet så åbenbar, at højagtelsen af dem skulle være sikret for al fremtid. Geografien og retsvidenskaben, hvem i Europa skulle vel i dag kunne drømme om at kunne undvære dem selv i det jævneste liv, og hvad skulle der da blive tilbage, hvis skæbne man kunne ængste sig for, og for hvis skyld vi skulle vige tilbage fra at føre vor viden ud af de dunkle kamre, ind $i$ det virksomme liv, for endelig engang at sætte handlinger $i$ stedet for denne viden, der længe nok er blevet vejet og pillet ved i ord?. Er det måske filosofien, er det måske tungens og håndens skønne kunster, disse åndelige blomster, som kun behøver den moderlige jord og den udødelige sol for at trives, som kun behøver at vise sig for at blive lovprist, kun behøver at dufte for at blive elsket. Ja, man spørger sig selv, hvor man taler bedst, dér hvor man kun øver sig i at deklamere, eller hvor det gælder - ikke blot at muntre, men at gribe et helt folk i dets stedfortrædere, at oplyse dem, at vinde dem for de ædleste følelser, de klogeste forholdsregler, eller vække dem til de dristigste, kækkeste beslutninger, de mest strålende handlinger, give dem mod og besjæle dem dertil! Hvor synger fuglene helst, i buret eller i den grønne skov, hvor klinger den største af alle sange: sangen om friheden, sangen om menneskebørnenes frie gøren og handlen, hvor klinger disse naturligere end under den frie himmel?

Det er ikke af disse livsglade børn, der trives bedst i den brogede vrimmel under de største gnidninger, man må vente sig bebrejdelser, men snarere af den gamle betænksomme kone, der ikke kan lide den støj, og som altid løber fare for at blive drillet en smule af de små fritløbende drenge, og at blive ringeagtet af de kraftige mænd, som henfører hvert ord til ting og handlinger.

$\mathrm{Vi}$ vil heller ikke betvivle, at denne under æresnavnet filosofi højagtede frue har berettigelse til at udtale sig ved vor side, thi som det jordiske lysriges anerkendte dronning kan hun i hvert fald kræve at blive understøttet i sine opgaver: i sine store bestræbelser for udbredelsen og forklaringen af lys-stoffet. Der turde dog i den henseende herske en lille misforståelse, idet den elskede, højtærede frue, udsprungen af Kronidens hjerne, nylig som også undertiden fordum, drevet af naturlig forkærlighed for det overjordiske, synes at have overilet sig og er steget lidt for højt, hvil- 
ket $\mathrm{i}$ hvert fald forårsager en farlig spænding mellem hende og mangen af hendes tidligere venner og tilbedere, som endog lod befrygte en fjendtlig spaltning, men vi stoler på, at den betænksomme ærede frue snart vil opdage, hvordan hun har rådført sig for meget med sin guddommelige herkomst og for lidt med sine jordiske forhold, og at det ikke er hendes tilbederes skyld, når de lænket til jorden ikke formår at svinge sig op med hende og derfor ser sig nødsaget til, dersom hun fremturer deri, at sige sig løs fra deres ikke ubetingede forpligtelser.

Denne sandsynligvis forestående opdagelse ville genoprette det naturlige forhold mellem den sunde menneskeforstand og fornuftideerne, og på det faste britiske grundlag ville tronen i så fald blive oprettet for dronningen til urokkeligt at trodse alle storme og bølger.

En livsfilosofi - hvorledes kunne den frygte at blive forstyrret $\mathrm{i}$ sin eftertænken af sin højesteretsadvokat, det frie, bevægelige liv, eller blive unddraget sine tilbedere? Vi véd det jo ganske vist, der gives endnu en ikke just himmelsk, men snarere underjordisk $æ-$ ret frue, der måske kunne ængste sig for sin beskæftigelse og sin ære, og hvis bekymringer vi næppe tiltror os evne til at bortrydde, thi vænnet til at bo i gravene mellem de døde, hvor hendes egen hvisken er den eneste støj, hendes dunkle natlampes skær det eneste lys, turde hun vel vanskeligt kunne trives i de højere, levende, lysfyldte regioner; men hvem kan fortænke de opvoksende ynglinge $\mathrm{i}$, at de - legende med de lænker, deres forfædre bar skyr fængselet, og omend den romersk-græske Proserpina ikke allervenligst indbyder dem til hendes lidet opmuntrende gæstebud, høfligst betakker sig og svarer: lad de døde begrave deres døde, vi går hen at forkynde de levende guddomsriget, at udtale og tilbede Livets genfødte Ord!

Ikke sandt, I oplyste mænd! Omtrent således ville eders gensvar lyde, og I ønsker måske i fuldt alvor at erfare, hvad der endnu skulle være at spørge om. Og dog, skulle det virkelig være undgået eders skarpsindighed, at der udover de fruer, I tænkte på, gives endnu én, og det hverken en overjordisk eller underjordisk, men en rent jordisk-menneskelig frue, der hævder sin ret til at udspørge eder om, hvorledes I tror at kunne tage ansvaret for at opsige hende, de Levendes åndelige dronning, huldskab og troskab. Det er Historien, der, idet hun svæver over gravene, og er dom- 
mer over de døde, oplyser, formaner, advarer og bedømmer de levende. Det er Historien, der løfter sin stemme og spørger: hvor vover I, øjeblikkets børn, at lade hånt om mig, dronningen over alle tider? Hvorledes tiltror I eder at vide, hvad jeg først $\mathrm{i}$ kommende dage tænker mig at afsløre? Hvorledes bilder I eder ind at have udtømt min tale, før end den endnu er udtalt! Hvor kan I blot drømme om at forstå det nærværende og udspejde det fremtidige uden at have udforsket og udgrundet det forgangne? Nævn mig dog engang noget stort eller blot noget menneskeligt, der blomstrer i nutiden og ikke har sin rod i fortiden; og kan I ikke det, hvor vover I da at tale om lys og visdom uden at være steget ned og op med mig, ned i jorden til de hedengangne slægter, og atter op til de levende? Véd I ikke, at ligesom hvert menneskebarn udgår af modersliv som af en grav, således bliver også ethvert nyt lys fremkaldt af mørket, at den åndelige visdom kun lader sig tilsyne ved en opstandelse fra de døde i forklaret skikkelse med forståelige taler til sine disciple! I ler ad min tjenestekvinde, som begraver de døde, og glemmer, at alt, hvad der findes latterligt $i$ hende, er eders egne hænders værk, den papirkrone, I blindfødte sætter på tjenestekvinden uden at spørge mig, uden at kende mig, mig, hvem svævende i norners dragt over tiderne, den guldkrone tilkommer, som I ærbødigt lagde for fødderne af eders kvindelige afgud, som tilbedt af eder under det stjålne navn af Filosofien opbyggede sine slotte i luften. $\mathrm{Nu}$ bilder I eder ind at være blevet vidunderligt kloge, fordi I har opdaget som en stor hemmelighed, hvad der dog springer i øjnene, at for mennesket på jorden opstår der ingen frelse, hverken af at tilbede den luftige gudinde eller af at have fællesskab med helvedesgudinden, og at den visdom, som skal tiltale menneskehjertet og fremme uddannelse og udvikling, hverken flagrer i luften eller roder i jorden, men nødvendigvis må være levende mellem de levende og bo på jorden. I bilder eder ind, at det er noget stort, og det er dog intet andet end (et) forfængeligt gøglebillede, idet I kun frasagde eder den forrige overtro for at tilfredsstille en ny falsk gudinde. Det er VerdensKlogskaben, der udspringer af den sanselige hverdagserfaring, denne den menneskelige ånds bortløbne tjenestepige, til hvem I ofrer eders børn ved en sand Molochs-tjeneste. Erfaring og menneske-kundskab, helligede navne på menneskelivets jordiske frugter som ånden, når den har fået forstand på sig selv, er kaldet 
til at indhøste - i hvilken grad berøver I dog dem deres hellighed, idet det kropslige for eder gælder alt; og den snedighed, hvormed I har forvundet tabet, og hvorved I eftersporer modpartens slethed, den kalder I vejen til den sande menneske-kundskab! Véd I da ikke, at mennesket kun kendes af den Ånd, som bor deri, og som giver sig tilkende, ikke i dyriske funktioner, men for den forstandige ånd i menneskelige gerninger, og som derved i sine virkninger bliver genstand for den åndelige erfaring? Kan I benægte det, at der gives en sådan erfaring, og at kun den kan forventes at føre mennesket til sand kundskab om sig selv: den vidunderligt kropsliggjorte ånd og åndeliggjorte krop, som Historien kalder menneske, og om hvis gådefulde væsen den allerede har ydet sine ydmyge dyrkere så store oplysninger. Dersom man ville foreslå eder at fælde afgørende dom over malerkunsten i det hele udelukkende efter de nutidige farveblanderes dyre- og blomstermaleri - et hånligt smil ville være eders ikke uforskyldte svar. Men er det da mindre tåbeligt at vurdere mennesket, dette uforlignelige guddommelige kunstværk efter dårlige, åndløse kopier, eller indser I da ikke, at hvem der vil vide, hvad mennesket er, først må undersøge, hvorledes mennesket har vist sig, har vist sig under alle omstændigheder, og at det mellem alle stortalende påstande er en af de tåbeligste at rose sig af menneskekundskab uden at have betragtet den samlede menneskehistorie, forstået den, endsige begrebet den. Kløvet har I ordet, men har I også forstået det? Også på Jorden lyder dets historie således: I begyndelsen var Ordet, alle ting er sket ved det samme, og i det var livet; forstår I det eller ej, som den nordiske Vølve siger. Det levende Ord, på én gang ånd og krop, det usynlige og dog sanselige billede af menneskeånden, vidner det ikke uimodsigeligt om det unægtelige fællesskab mellem himmel og jord, er det ikke, hvad I modsigende (d.e. protesterende) kalder en kropslig ånd og en åndelig krop! Er det ikke tåbeligt at bilde sig ind, at gerningerne var store, men det Ord, der skabte gerningerne, var en småting, at virkningerne var større end årsagen og lod sig tilfredsstillende forklare uden at blive opsporet i den og afledet af den! Har ikke ethvert ord, der skabte gerninger, den ubetvivlede ret til at blive overvejet og vurderet efter disse, og tvinger fornuften eder ikke til at kanonisere og dyrke det vægtigste blandt alle ord som det højeste menneskelige udtryk for ånden og sandheden, som et Guds-Ord! 
Hvad er da alt, hvad I sagde om poesien, om myterne, om folkenes dvs. menneskebørnenes hellige skrifter og heroiske tider, hvad er det andet end tom snak, dersom I endnu tror at kunne overgå og nedgøre hine ord, som gav de døde liv og lagde bånd på ånderne, som opbyggede og fyldte kirkerne, som skabte og opretholdt staterne, som århundreder igennem drev, ildnede og styrkede folkene til den mest levende virksomhed, til strålende liv og kærlighedsrig død for Åndens sag - ved et ord, som for det meste synker dådløst til jorden, i det højeste for et øjeblik opheder hovederne, og som bevæger kroppene i deres dyriske retning og tankerne i deres naturlige retning. Eller tror I virkelig at sige noget fornuftigt, når I forklarer de store, herlige, for eder uopnåelige virkninger af det poetisk, åndeligt levende ord som forårsaget af åndens forvildelser, af sværmeri og overtro? Forekommer det eder muligt, at menneskeånden flyver højere end sig selv, og bliver stærkere, når den forvilder sig, end når den slår ind på den rette bane, som er bestemt for den, og frygter I alligevel ikke for, at galehuslemmerne i dag eller i morgen rejser en ny trone for den forvildede ånd på ruinerne af eders fornuftigste og på asken af eders sandfærdigste skrifter -

Således taler Historien, eller således taler $\mathrm{i}$ det mindste her et menneske i Historiens navn, og I er jo dog alt for kloge til at tro, at den slags bebrejdelser kan besvares grundigt på anden måde end gennem den oplyste Historie, og nu spørger jeg: ligger virkelig alting klart for dagen, hvad der er kommet til os fra de forgangne tider, og hvis det ikke forholder sig således, hvordan kunne den historiske kritik da fuldbyrde sit arbejde? Sømmer det sig måske bedre for den, der udtaler sig om hele menneskeslægtens jordiske liv som om dens fremtidige skæbne, hvilket filosoffen jo må gøre, sømmer det sig bedre for ham end for sognefogeden, når han behandler den mindste sag, at fælde dommen ensidigt uden at have lyttet til vidnerne på behørig vis?

Når jeg hævder, at alle tiders historie med ord og gerninger bevidner, at mennesket, når det - som det nu er tilfældet - hengiver sig til det jordiske, ikke blot fornedrer sig, men også undergraver og ødelægger sin jordiske velfærd, og at det derfor, hvis det er klogt, nødvendigvis hellere må finde sig i den hårdeste underkastelse og den dybeste armod end gøre sig fremmed for det åndelige liv og de himmelske forhåbninger, hvorledes kan I da gendrive 


\section{en sådan påstand uden at være Historiens mestre, og hvorledes står Historien eder til tjeneste, dersom...}

(Her slutter manuskriptet, nederst på bagsiden af et blad, men midt på en linie og uden noget punktum. Grundtvig har - som det ses heraf - opgivet at fortsætte og fuldføre både manuskriptet og sætningen. Om årsagen hertil kan man kun fremsætte formodninger. Om han har opgivet at overbevise de tyske læsere, eller er veget tilbage for de handlinger fra tyske professorer han har fremsat ønsket om, kan man kun gisne. Det sandsynligste er, at begivenhederne er kommet Grundtvig i forkøbet, de begivenheder, han selv meget senere - i 1838 - har talt om i sit 38. foredrag om verdenshistorien i "Mands-Minde" - "om Tyskheden i og for sig selv, som den susede og brusede om vore Øren i Aarene 1815-20" (Svend Grundvigs udgave, 1877, s. 306ff).). 